\title{
The Development of Economic and Social Indicators in V4 Countries
}

\section{Pavol Schwarcz, Marián Kováčik, Maroš Valach}

Department of European Policies, Faculty of European studies and Regional Development, Slovak University of Agriculture in Nitra

Tr. A. Hlinku 2, 94976 Nitra, Slovakia

pavol.schwarcz@uniag.sk,marian.kovacik@uniag.sk, maros.valach@uniag.sk

\begin{abstract}
After the transition from a centrally planned economy to a market-based economy, and following EU membership, there were significant changes in particular branches of national economies in new member states, thereby reducing the self-sufficiency of these economies. In particular, we focused on central European countries. The aim of the paper was to assess the development of economic and social indicators in particular branches of national economies. To study the situation in these branches we focused on the following social and economic indicators, e.g. employment rate, unemployment rate by branches, people at risk of poverty, salaries in selected branches, gross fixed capital formation, share on GDP, the balance of payments and foreign direct investments. Furthermore, we studied the development of particular indicators in transition period followed by assessing their correlation to each other using appropriate statistical methods. In general, we assumed a positive correlation between the majority of social and economic indicators. In the end, these results were compared in chosen central European countries.
\end{abstract}

Keywords: gross domestic product; foreign trade; poverty risk; sectoral unemployment; gross fixed capital formation

\section{Theoretical Framework}

European countries endured many positive and negative experiences during the $20^{\text {th }}$ Century. Among the most affecting can be counted two world wars which led to chaos and insecurity of inhabitants. After World War II the major participants in war decided to prevent further conflicts and ensure peace in Europe. Thus, began the path of creation of the European Economic Community, which could be seen as the beginning of an economic union which was aimed at strengthening the economic cooperation among its member states. This cooperation led to the creation of the European Union. 
Not only western European countries had to undergo turbulent periods. In central European countries there was the communist arrangement which did not affect only personal rights but also the national economy as a whole. This was mainly due to the centrally planned economy which stated plans for production. Due to this arrangement, the western countries labelled these countries as a "commercial black hole". This period can also be characterized by lower consumer prices in comparison to the world market, inefficient production and distribution system, excessive demand after foreign products which led to rationing and queuing. In general, the poorer the country the higher the income disparities on a regional level (Nagy, 2016). After the collapse, the situation got worse because there was a sudden decline in production which led to decrease of GDP per capita and was accompanied by inflationary pressure as the central bank attempted to mitigate this decline to save state enterprises. Further disadvantages were high public debt, low productivity and lastly fear of political, economic and social changes accompanying the transformation process and sectoral changes. The post-soviet countries, in general, went through several currency crises during 1998 - 1999 and 2008 - 2009 periods followed by latest in $2014-2016$ period questioning their macroeconomic stability and social assistance system. (Healey, 1994; FAO, 1995; Dabrowski, 2016; Androniceanu, Tvaronavičienè, 2019; Jašková, 2019).

Negative impacts can be reduced by foreign direct investments (FDI). In a study carried out by Gnangnon (2018), there is a correlation between multilateral trade policy (MTP) and FDI and structural economic vulnerability (SEV) and FDI. His study shows us that MTP encourages the outward FDI and the SEV is discouraging it. These results show us that with lowering the countries development level the MTP impact on FDI is rising and SEV impact is decreasing. Economic growth also depends on economic freedom in a country which can be measured by the Index of Economic Freedom. Various authors study this index and its relation to indicators characterising the source of the economic system. In a study carried out by Mura et al. (2017) the results showed us that Index of Economic Freedom has an important impact on the identification of the mutual relationship between the Index of Economic Freedom and indicators characterizing source sufficiency, public sector, autonomy and the economic stability.

As a result, these changes also affected the sectoral employment. The transition period is associated with the reallocation of the labour force. This shift could be observed from the public sphere to the private sphere as well as between the different industries. This shift had an impact on two important indicators. Firstly, there was a change in the level of education due to the necessity to acquire new knowledge and skills and, secondly, there was a change in regional employment structure (Rutkowski, 2006). The Czech Republic and Slovakia went through major societal changes after 1989 which resulted in the desire of employees for corporate culture (Hitka, et al., 2018). During this period the labour market had undergone many changes, while in the 1990s it was due to extensive growth later 
on, from 2000 it was due to new opportunities arisen from the membership in EU. The employment rate in V4 countries was higher than in the old member states. The V4 countries had shown similarities in decreasing employment in the agricultural sector and increase in the sector of services. This growth was the result of a competitive effect of membership (Bielik, Rajčániová, 2008). When considering educational level, the higher career degree means higher financial incentives, but it does not contribute to a higher motivation level. Employees with higher motivation levels are more satisfied with their work (Mura, Vlacseková, 2018).

One of the present competitive advantages of Slovakia, and other later EU member states, was a low-cost based economy to attract more foreign investors (Civelek et al., 2019). Among these advantages, we can count low wages and relatively low taxes compared to other European countries. Unfortunately in the global economy, these factors can no longer be seen as sustainable and therefore the countries need to focus more on advantages connected to resources, especially human resources. The potential can be seen in intellectual capital and innovative enterprises. Innovative leaders in the EU can be seen in the business sector, mainly in small and medium enterprises. Unfortunately for Slovakia, it is the least innovative economy among the V4 countries and EU member states focusing more on maintain partnerships and supply chain optimization (Volná, Papula, 2013; Čepel, 2019). Creation of EMU may seem like an attempt of creation of optimal currency area. Despite some disputes, officially this term was firstly mentioned by Robert A. Mundell in 1961. His theory states that maintaining national currencies needs not be the most efficient arrangement. Creation of common currency may allow deeper integration of countries and markets. On the other hand, the countries need to give up the options for influencing fiscal and monetary policies. Furthermore, he states that creation and functioning of OCA require the following four criteria: labour mobility, capital mobility (including prices and wages), similar business cycle and currency risk-sharing system. The latter was not fully implemented in EMU and the results were seen during the financial crisis which some authors refer to as "European Sovereign Debt Crisis" (Kräussl, Lehnert and Stefanova, 2016; Floyd, 2016). Some claim that the labour market in the European Union compared to other global labour markets, e.g. North America, is less flexible and therefore the unemployment rate is higher. These differences can be seen job vacancies, national or international mobility of labour force, level of education and other skills and even gender differences. In the case of Slovakia, there do not exist any differences in the assessment of corporate culture based on gender (Nickell, 1997; Pavlíková, Siničáková, 2012). Furthermore, the unfavourable conditions in the labour market combined with the impacts of the global financial crisis during the 2007 - 2008 period led to insecurity in various areas like employment, taxes and public revenues and public sector. Among younger people, there are problems with acquiring their own homes. Lennartz and his colleagues undertook a study which resulted in confirmation of decreasing home-ownership among young people up to 34 years 
but also a very slight rise in renting. Their results show us that there is a transformation process going towards co-residence of people with their parents (Lennartz, Arundel, Ronald, 2015; Androniceanu et al., 2019; Okanazu, 2019). The impact of economic crisis can be divided into two basic groups, macroeconomic and microeconomic. Indicators which help us measure macroeconomic impacts are GDP, inflation, loan repayment and unemployment. Microeconomic impacts can be measured by the level of previously mentioned indicators in four target groups - individuals, companies, regions and industries (EEIP, 2010).

Entering the EU meant for all new member states change in foreign trade. These changes were connected to the adoption of several principles like free movement of goods and services, common tariffs as well as the removal of certain physical and non-physical barriers to trade inside the Community market (Czaja, Wach, 2009). Before the outburst of crisis, the export was slightly higher than the imports, however, this situation changed at the end of 2008. The previous growth of export was the result of transnational companies and high demand in developing countries, particularly in investments projects focused on electronic services. After the global financial crisis hit the economies of several states there occurred negative trade balances around the world. When considering our studied countries Poland was one of the luckiest countries which did not fall into recession. While the GDP of EU-28 was decreased by $4.5 \%$ the GDP of Poland was increased by almost $2 \%$. However, also in Poland, there was a decrease in the export of intermediate products and raw materials. (Bloomberg, 2009; PWC 2010; Mitrega-Niestroj, 2011). This situation was achieved due to several factors, like strong internal market combined with a business-friendly political environment. The public debt was about 50\% of GDP which was a result of strict financial regulation which also helped keep private debts low. Also, in comparison of other European countries, Poland did not fully implement saving policies but focused on domestic demand via tax cuts and foreign assistance (Drozdowicz-Bieć, 2013). Despite the loss of złoty value Poland did not get to be threatened by financial turmoil like in any other countries. The weaker currency helped the exporters to deal with the rapid decline of foreign demand (PWC, 2010). It may seem that Poland was the least affected country which maintained positive GDP growth even during the financial crisis. This could be the result of high investments and growth before the crisis outburst. It is also necessary to point out that this situation did not last long due to interaction and mutual economic dependence with its neighbours. From a social point of view, there also was an increase in unemployment like in other countries (Reichardt, 2011; Miłek, 2018). The global financial crisis is connected to smaller job creation and higher job destruction which further threatens regional stability. Growth of employment rate in Poland was almost $4 \%$ lower during the 2009-2010 period. Location of regions also plays an important role in the quality of life and employment, especially those located in central and north-western Europe (Chocholatá, Furková, 2018; Nowak, 2018; Chehabeddine, 2020). But on the other hand, the study conducted by Hagemejer 
and Tyrowicz (2017) shows us that the rate of job creation is higher than job destruction. The overall employment growth is dependent on the position of the sector in the production chain. In manufacturing, faster employment growth occurred further away from the final demand. This effect is mostly due to the difference in job creation rates along the production chain as is for the job destruction. Considering the labour markets in new member states indicates that social cohesion was a bigger problem than it appears on simple studies based on Gini coefficients (Tomkiewicz, J., 2018).

After entering the EU, the Czech Republic had one of the best economies in central Europe. This situation was gained through economic openness when foreign investors controlled more than $95 \%$ of large financial and $70 \%$ of nonfinancial companies in the country, which meant that Czech became highly dependent on a decision made abroad. The growth of real GDP was 5\% on average and GDP per capita from $73 \%$ to $80 \%$ of the EU average during the 20032008 period. This performance was gained due to effective macroeconomic and structural policies applied. But due to the export-oriented trade policy, the economy was slowed down when exports and industrial production fell by $18 \%$. This led to strict conditions and decrease of FDI by 7.4\% in the first half of 2009 following the rising unemployment rate with decreasing number of job vacancies. The government reacted by several measures like cuts is social security contributions, increased public investments business and employment support. Unlike other countries, the Czech Republic does not have to face several threats of internal imbalance due to the debt crisis. The Czech Republic maintained its high credibility and, strong banking sector and moderate foreign debt. (EC, 2009; PWC, 2010; Tvrdoň, 2010; EEIP, 2013). However, from a political point of view, the crisis resulted in the collapse of government which affected also the market. The higher impact could be felt on the currency market when the Czech crown fell to 27.3 to EUR from 26.91. Compared to other central and eastern European and Baltic countries this political instability was not so threatening because the financial crisis was mainly the result of decreased external demand for their production (Ram, 2009). Relative growth of demand is highly influencing factor on the positive trade balance, especially in manufacturing, in the Czech Republic as well as in Poland. This connection is mainly due to entering the EU and gaining European and global access to markets. The positive impact can also be achieved by expenditure on $\mathrm{R} \& \mathrm{D}$. This positive development in the trade balance is also strongly connected to labour productivity. However, the positive trade balance can be jeopardized by government policies because these raise the minimum wage faster than average labour productivity (Dul'ová, et al., 2017; Olczyk, Kordalska, 2018).

In Hungary, the situation was different from the beginning because its economy has been weaker since before the global financial crisis. Labour productivity was decreasing and indebtedness was increasing. The general government deficit was $9.3 \%$ of GDP in 2006 whereas the GDP growth was only by $4 \%$. The political 
measures helped to decrease the budget deficit to $3.8 \%$ by 2008 but were not focused on important structural reforms. Therefore, the GDP growth was lower in comparison to other neighbour countries. Similar to the Czech Republic also Hungary is an export-oriented economy, mainly to Germany, which was unfavourable due to decreasing external demand. (EC, 2009; PWC, 2010). After the crisis outbreak, the Hungarian forint weakened by $17 \%$ compared to EURO. This decrease led to household's insolvency and credit crisis. It also led to a decrease in loans and mortgages. Based on the survey conducted by Egedy, people see the biggest crisis impacts in the cities in the area of employment and job opportunities, problems in real estate markets, business environment and financial shortages and funding problems (Egedy, 2012). Main problems of the national economy were low performance, low international competitiveness, and low amount of natural resources, small domestic market, unfavourable demographic trends and quantitative and structural problems of the labour force (Békesi, 2011). One of the most important lessons to be learnt from international examinations is that active labour market programmes are effective if they can ensure wellrounded complex solutions while concentrating on a special problem. In the case of Hungary, these programmes do not serve as long-term solutions and did not result in decreasing long-term unemployment (Cseh Papp et al., 2018).

Before the global financial crisis, Slovakia, with GDP growth of $7 \%$, was considered as one of the best performing member states of the EU. From a macroeconomic point of view, the balance was maintained due to sound macroeconomic and structural policies adopted by the government. Along with the inflation rate between 2-5\% it was ready to adopt Euro in 2009. However, similar to the Czech Republic, it is an open economy depending on export due to weak internal market. This also proved to be a negative side after the outburst of the financial crisis. This situation was worsened by the fact that Slovakia is mainly focused on the production of automobiles which negatively affects other sectors of the economy. The export rate was decreased by $25 \%$ and with a higher decrease in imports, the private sector and households started to save more. As a result, private investments and consumption fell by $4.6 \%$ and $4.8 \%$ respectively. The economy was holding quite well thanks to the adoption of EURO. As a response, the government approved measures focused on specific aspects of the economy, disadvantaged groups and support of employment. Unlike in Poland, Slovakia is vulnerable to financial turmoil, but there should not be problems with the stability of the currency, especially with moderate levels of private and public debts. (Bajer, 2009; EC, 2009; PWC, 2010).

Entering the EU meant access to new markets. This internal market generated in 2014 almost $80 \%$ of total exports of Czech Republic, Slovak Republic and Hungary. The largest economic partner, and the main source of foreign direct investments in these countries has been Germany since the early 1990s. This partnership led to a strong automobile and electronic industry, particularly in the Slovak Republic. Among the V4 countries, the strongest relationship was, 
traditionally, between Slovak and Czech Republics. The central European countries have several advantages compared to other competing economies. Firstly, they have good geographical locations, bordering to other larger economies in EU like Germany. Secondly, good labour force conditions like low costs and good educational base. The rapid transformation also meant that these countries already had a stable macroeconomic environment. The fourth advantage was a well-established domestic industrial tradition as a result of state industries under the previous regime. (Baláž, et al. 2016). Economic conditions of the country do not have an impact on the national economy but also a quality of inhabitant's life. In the past, many authors faced many possibilities of defining the meaning of quality of life. They tried to define the condition of good quality of life and setting the correct indicators to measure them (Scanlon, 1993). Quality of life, in general, can be defined as the well-being of societies and individuals with all the positive and negative features. This term can be used to describe the life satisfaction, health, and level of education, sociology, psychology, political science, employment, environment and financial status (Andrejovský et al., 2012; Barcaccia et al., 2013). The rapid changes in the quality of life have resulted from rapid globalization activities affecting the national economy. In general, we can use indicators such as GNP, GDP, GDP per capita, inflation (Stiglitz et al., 2009). In the end, we need to remember that measuring the quality of life is a very complex concept influenced by many economic, social, cultural and environmental factors. To measure the quality of life we can use indicators such as Human development index which reflects health, education and living standards (Beslerová, Dzuričková, 2014).

Although the institutional and structural developments have varied in our cases the development and changes in poverty in rural and urban areas were similar. Similar conclusions were achieved by studying rural-urban poverty in transition countries by Macours and Swinnen (2008) or Kisel'áková et al. (2018). They identified several patterns related to the development of poverty. Among others, there was a government distribution of land to rural households to cope with the transition by self-employment. This process meant the destruction of existing agricultural cooperatives. In post-soviet countries located in Asia, this was a good step to promote employment in rural areas. On the other hand, in central and eastern European countries was not measured a comparable success. Agriculture remains the main source of income and employment in the poorest countries. Nevertheless, technological progress played an important role in increasing the labour productivity which has a positive influence on growing added value but on the other hand, this growth can have a negative impact on the employment rate. However, labour productivity is only a portion of the indicators which can affect employment. Among others, we can include changes in economic structure. Firstly, there was an increase in consumption of imported goods and secondly a decreasing trend in domestic consumption. Other changes were recorded in links among sectors in the national economy. These changes can be either positive or negative (Hudcovský, et al., 2017). 


\section{Data and Methodology}

The main objective of the paper was to find out whether the economies of the countries after transition periods and later entering EU were improved. To achieve this objective we decided to study the chosen social and economic indicators to observe their development. The partial objective was to determine whether there was a relation between social and economic development in the countries to confirm that not only the macroeconomic situation but also the living standards of the population were improved. The material of this paper consists mainly of secondary official statistical sources, e.g. Statistical office of the European Union (Eurostat) and national statistical offices related to the V4 region. In observation, we used the following indicators in the period from 2008 to 2016: GDP per capita, unemployment rate, labour productivity per hour, gross annual earnings, FDI stocks inward in million Euro, people at risk of poverty or social exclusion.

Firstly, we analysed these indicators in V4 countries and used charts for illustration. And secondly, we used correlation analysis to find the dependency between the selected groups of economic and social indicators. For this purpose, we conducted the calculations in the SAS programme.

Correlation analysis is a method of statistical evaluation used to study the strength of a relationship between two, numerically measured, continuous variables. Pearson's product-moment coefficient is the measurement of correlation and ranges between +1 and $-1 .+1$ indicates the strongest positive correlation possible, and -1 indicates the strongest negative correlation possible. Therefore, the closer the coefficient to either of these numbers the stronger the correlation of the data it represents.

Pearson's correlation coefficient

$$
\rho x, y=\frac{E[X Y]-E[X] E[Y\rceil}{\sqrt{E\left[X^{2}\right\rceil-[E[X]]^{2}} \sqrt{E\left[Y^{2}\right]-[E[Y]]^{2}}}
$$

$\sum \mathrm{xy}=$ sum of the products of paired scores

$\sum \mathrm{x}=$ sum of $\mathrm{x}$ scores

$\sum \mathrm{y}=$ sum of $\mathrm{y}$ scores

$\sum \mathrm{x} 2=$ sum of squared $\mathrm{x}$ scores

$\sum \mathrm{y} 2=$ sum of squared y scores 


\section{Results and Discussion}

The following chapter is divided into two basic parts. The first parts focus on the graphic description of selected indicators and their development in V4 countries from 2005 to 2017 . We focused on basic economic and social indicators to see the differences in quality of life on one hand and the quality of the business environment on the other hand.

When comparing the living standards among our countries we can use a GDP per capita indicator (in \% of EU average) which stands for economic output for the countries' number of inhabitants. The best situation among our studied countries can be seen in the Czech Republic and the Slovak Republic (Figure 1). But on the other hand, we need to underline the fact that large and performing countries usually have lower values of GDP per capita because the GDP is divided among all of its inhabitants. Since Hungary and Poland have a larger population, therefore, this indicator is lower than in other countries.

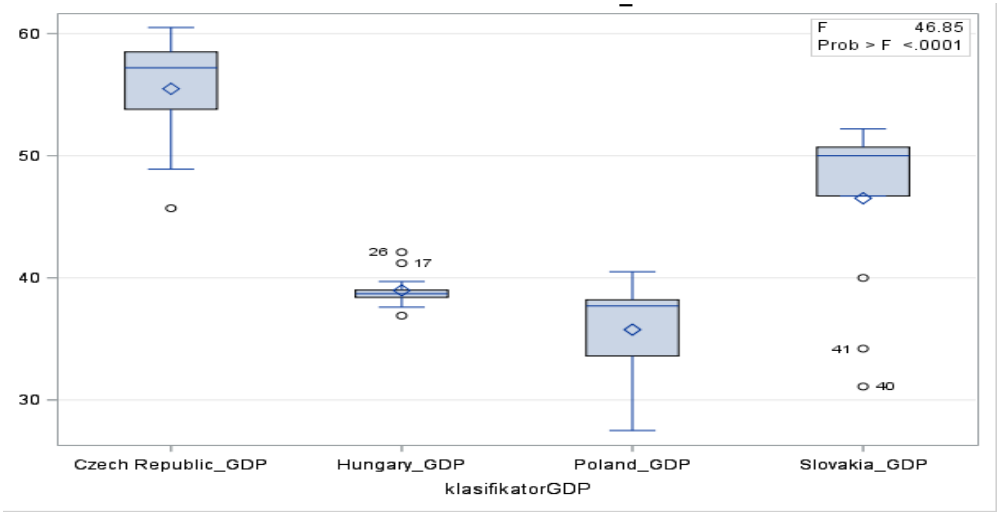

Figure 1

GDP per capita in \% of the EU average

As a result of the global financial crisis, the number of unemployed people was constantly rising until 2010, which is considered as an end of this crisis. From this year onwards the number of unemployed was slightly decreasing in all countries almost to the level of pre-crisis. The highest number of unemployed people during the examined period was recorded in Poland and the lowest in the Czech Republic (Figure 2). 


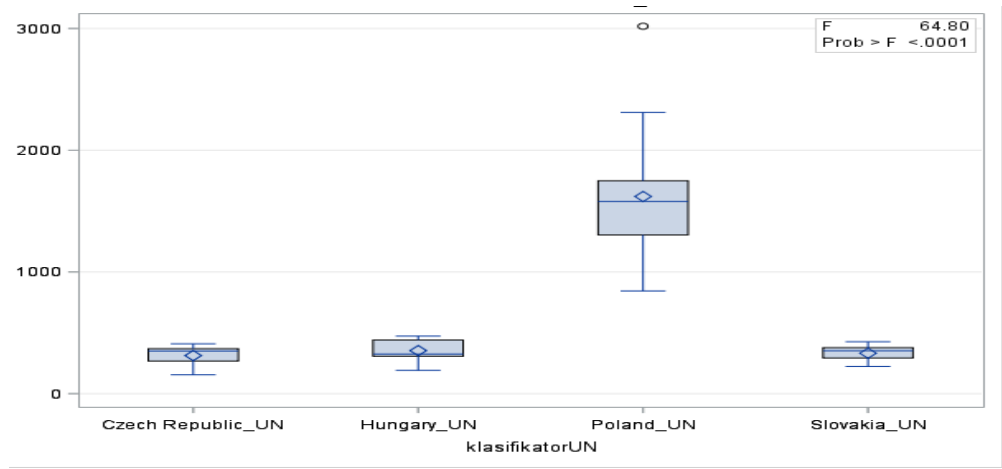

Figure 2

Number of unemployed people in thousands

Labour productivity increased during our examined period in all countries. The best situation among our studied countries can be seen in the Slovak Republic (Figure 3), where labour productivity increased from $10.60 €$ per hour in 2005 to $20.90 €$ per hour in 2017 . The second-highest labour productivity was observed in the Czech Republic. On the other hand, the lowest level of labour productivity was recorded in Poland, in 2017 it was $14.10 €$ per hour.

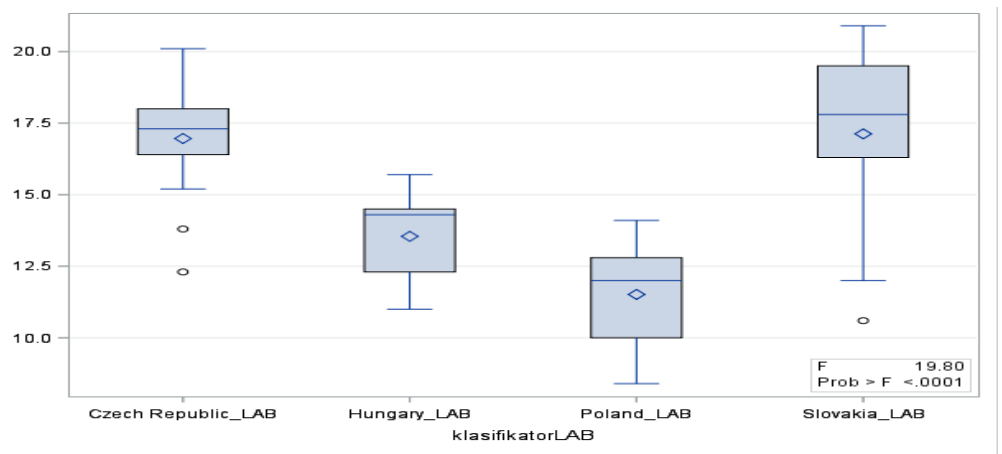

Figure 3

Labour productivity per hour in $€$

Direct investments were increasing in all countries except for the Slovak Republic where a slight decrease from the level of $71.20 \%$ of GDP in 2005 to $68.60 \%$ of GDP in 2017 can be observed. A dramatic increase in direct investment was recorded in Hungary, in 2017 they have reached 214.70\% of GDP (Figure 4). The development of direct investments in the Czech Republic and Poland had a similar trend until 2014 when there occurred differences in the further amount of direct investment inflow in favour of the Czech Republic. 


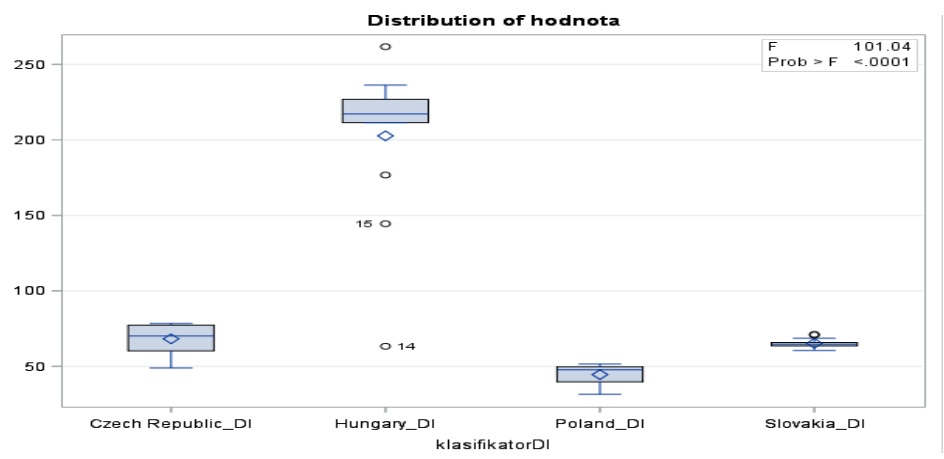

Figure 4

Direct investment in the reporting economy in \% of GDP

A relatively stable trend with a slight decrease in people at risk of poverty can be seen in all countries except for Poland (Figure 5). In the examined period the number of people at risk of poverty decreased almost by 10 million (57.40\%). This situation can be due to the result of a significant increase in gross annual earnings and a decrease in the number of unemployed persons after 2012.

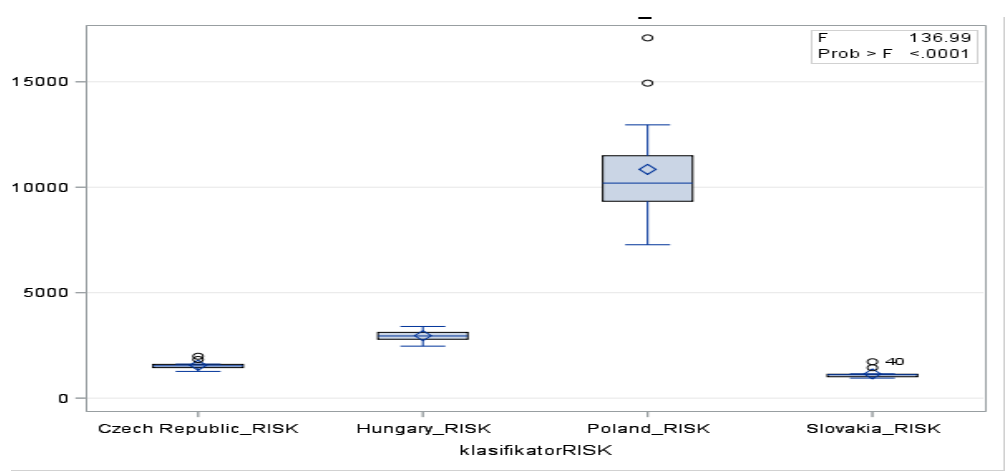

Figure 5

People at risk of poverty or social exclusion in thousands

Table 1 presents descriptive statistics of chosen indicators in the Czech Republic. Direct investments have achieved an average value of $68.20 \%$ of GDP during the examined period. In the case of employment, the minimum value of 5,118 thousand pe was recorded in 2005. On the other hand, a maximum of 5,248 thousand people was achieved in 2017. The average GDP per capita was $55.48 \%$ of the EU average, which is the highest value among our studied countries. The Czech Republic reached also the highest value of Gross fixed capital formation in a total of $347.4 \%$ of GDP. Labour productivity per hour in the Czech economy was in average 16.96 EUR, which is the second-best result after Slovakia. Between 2005 and 2017 we can observe a decrease in the number of people at risk 
of poverty or social exclusion of 721 thousand persons. In the case of unemployment, the Czech Republic has achieved the lowest average value of 313.08 thousand persons.

Table 1

Descriptive statistics of chosen indicators, Czech Republic

\begin{tabular}{|c|c|c|c|c|c|}
\hline \multicolumn{7}{|c|}{ Simple Statistics } \\
\hline Variable & Mean & Std Dev & Sum & Minimum & Maximum \\
\hline Czech Republic_DI & 68.20000 & 10.40385 & 886.60000 & 48.90000 & 78.40000 \\
\hline Czech Republic_EM15 & 5182 & 39.87931 & 67369 & 5118 & 5248 \\
\hline Czech Republic_GDP & 55.48462 & 4.45081 & 721.30000 & 45.70000 & 60.50000 \\
\hline Czech Republic_GFCF & 26.72308 & 1.59015 & 347.40000 & 24.70000 & 29.50000 \\
\hline Czech Republic_LAB & 16.96154 & 2.11681 & 220.50000 & 12.30000 & 20.10000 \\
\hline Czech Republic_RISK & 1557 & 186.09027 & 20246 & 1267 & 1988 \\
\hline Czech Republic_UN & 313.07692 & 77.73509 & 4070 & 155.00000 & 410.00000 \\
\hline
\end{tabular}

In Table 2 we can see the results of descriptive statistics of chosen indicators in Hungary. Direct investments have reached an average value of $202.69 \%$ of GDP, which is the highest value among analysed countries. The minimum value of employment was recorded in 2009 (4,135 thousand people). And the maximum value of 4,565 thousand people was achieved in 2017. The average GDP per capita was $38.96 \%$ of the EU average, with this result Hungary is at the $3^{\text {rd }}$ place among V4 countries. Gross fixed capital formation in total was $281.70 \%$ of GDP. The average value of this indicator for the examined period is $21.66 \%$ of GDP. Labour productivity per hour in the Hungarian economy was in average 13.54 EUR, with this result Hungary is at the $3^{\text {rd }}$ place. The number of people at risk of poverty or social exclusion has decreased by 720 thousand people. The maximum value of this indicator (398 thousand per) was observed in 2013. Hungary has reached an average unemployment rate of 354 thousand people.

Table 2

Descriptive statistics of chosen indicators, Hungary

\begin{tabular}{|c|c|c|c|c|c|}
\hline \multicolumn{7}{|c|}{ Simple Statistics } \\
\hline Variable & Mean & Std Dev & Sum & Minimum & Maximum \\
\hline Hungary_DI & 202.69231 & 50.40932 & 2635 & 63.30000 & 261.70000 \\
\hline Hungary_EM15 & 4292 & 155.49676 & 55795 & 4135 & 4565 \\
\hline Hungary_GDP & 38.96923 & 1.37622 & 506.60000 & 36.90000 & 42.10000 \\
\hline Hungary_GFCF & 21.66923 & 1.67650 & 281.70000 & 19.20000 & 23.80000 \\
\hline Hungary_LAB & 13.54615 & 1.50090 & 176.10000 & 11.00000 & 15.70000 \\
\hline Hungary_RISK & 2961 & 274.51909 & 38489 & 2465 & 3398 \\
\hline Hungary_UN & 354.00000 & 91.67788 & 4602 & 192.00000 & 473.00000 \\
\hline
\end{tabular}

Table 3 presents descriptive statistics of chosen indicators in Poland. Direct investments have achieved an average value of $44.53 \%$ of GDP, which is the 
lowest value among studied V4 countries. In the case of employment, the minimum value of 16,610 thousand people was recorded in 2007. On the other hand, maximum of 17,150 thousand people was achieved in 2014. Poland has reached the lowest average value of GDP per capita (35.75\% of the EU average). Gross fixed capital formation in total was $261.40 \%$ of GDP, which is again the lowest value among V4 countries. The average value of this indicator for the period $2005-2017$ is $20.10 \%$ of GDP. Labour productivity per hour in Poland was 11.51 EUR on average. Between 2005 and 2017 we can observe a decrease in the number of people at risk of poverty or social exclusion of 9807 thousand people. In the case of unemployment Poland has reached the highest average value of 1,620 thousand people.

Table 3

Descriptive statistics of chosen indicators, Poland

\begin{tabular}{|c|c|c|c|c|c|}
\hline \multicolumn{7}{|c|}{ Table 3: Descriptive statistics of chosen indicators, Poland } \\
\hline Variable & Mean & Std Dev & Sum & Minimum & Maximum \\
\hline Poland_DI & 44.53846 & 6.46601 & 579.00000 & 31.50000 & 51.50000 \\
\hline Poland_EM15 & 16934 & 170.48404 & 220144 & 16610 & 17153 \\
\hline Poland_GDP & 35.75385 & 4.02153 & 464.80000 & 27.50000 & 40.50000 \\
\hline Poland_GFCF & 20.10769 & 1.59398 & 261.40000 & 17.70000 & 23.10000 \\
\hline Poland_LAB & 11.51538 & 1.71894 & 149.70000 & 8.40000 & 14.10000 \\
\hline Poland_RISK & 10846 & 2727 & 140994 & 7273 & 17080 \\
\hline Poland_UN & 1620 & 560.71330 & 21061 & 844.00000 & 3018 \\
\hline
\end{tabular}

In Table 4 we can see the results of descriptive statistics of chosen indicators in the Slovak Republic. Direct investments in Slovakia were on average at the level of $65.26 \%$ of GDP. The minimum value of employment was observed in 2005 (2,636 thousand people) and the maximum value of 2,738 thousand people was achieved in 2016. The average GDP per capita was $46.51 \%$ of the EU average, which is the second-best result after the Czech Republic. Gross fixed capital formation in total was $303.60 \%$ of GDP. The average value of this indicator for the examined period is $23.35 \%$ of GDP; it is the second-best result among analysed countries. Labour productivity per hour in the Slovak economy was in average 17.12 EUR (the highest value). The number of people at risk of poverty or social exclusion has decreased by 774 thousand people. The maximum value of this indicator (1 724 thousand people) was observed in 2005 and the minimum was achieved in 2016. The Slovak Republic has reached an average unemployment rate of 332.69 thousand people; it is the second-best result after the Czech Republic.

Further, we decided to measure the relations between selected economic and social indicators to find mutual relations and possible causes of the current economic situation in V4 countries. 
Table 4

Descriptive statistics of chosen indicators, Slovakia

\begin{tabular}{|c|c|c|c|c|c|}
\hline \multicolumn{7}{|c|}{ Simple Statistics } \\
\hline Variable & Mean & Std Dev & Sum & Minimum & Maximum \\
\hline Slovakia_DI & 65.26923 & 3.19332 & 848.50000 & 60.50000 & 71.20000 \\
\hline Slovakia_EM15 & 2688 & 31.70295 & 34943 & 2636 & 2738 \\
\hline Slovakia_GDP & 46.51538 & 6.90891 & 604.70000 & 31.10000 & 52.20000 \\
\hline Slovakia_GFCF & 23.35385 & 2.59249 & 303.60000 & 20.70000 & 27.30000 \\
\hline Slovakia_LAB & 17.12308 & 3.15414 & 222.60000 & 10.60000 & 20.90000 \\
\hline Slovakia_RISK & 1147 & 222.37988 & 13769 & 950.00000 & 1724 \\
\hline Slovakia_UN & 332.69231 & 59.88654 & 4325 & 224.00000 & 427.00000 \\
\hline
\end{tabular}

Table 5

Correlation of selected indicators in V4 countries

\begin{tabular}{|c|c|c|c|c|}
\hline & Czech Republic & Hungary & Poland & Slovakia \\
\hline DI - EM15 & 0,84844 & 0,369 & 0,66844 & $-0,35801$ \\
\hline DI - GDP & 0,69347 & 0,2725 & 0,92698 & $-0,61074$ \\
\hline DI -GFCF & $-0,86826$ & $-0,67889$ & $-0,43729$ & 0,38615 \\
\hline DI - LAB & 0,90485 & 0,74594 & 0,92725 & $-0,4951$ \\
\hline DI - RISK & $-0,84204$ & $-0,36414$ & $-0,9121$ & 0,80429 \\
\hline EM15 - GDP & 0,62694 & 0,38208 & 0,60602 & 0,84124 \\
\hline EM15 - GFCF & $-0,80393$ & $-0,34681$ & $-0,46388$ & $-0,81807$ \\
\hline EM15 - LAB & 0,79527 & 0,67362 & 0,57793 & 0,92364 \\
\hline EM15 - RISK & $-0,88396$ & $-0,55683$ & $-0,58553$ & $-0,79879$ \\
\hline GDP - GFCF & $-0,45079$ & $-0,012$ & $-0,2784$ & $-0,87082$ \\
\hline GDP - LAB & 0,87337 & 0,48568 & 0,96258 & 0,96166 \\
\hline GDP - RISK & $-0,8186$ & $-0,73435$ & $-0,94794$ & $-0,9186$ \\
\hline GDP - UN & $-0,44378$ & $-0,55098$ & $-0,77703$ & $-0,34397$ \\
\hline GFCF - LAB & $-0,6939$ & $-0,71639$ & $-0,44561$ & $-0,84287$ \\
\hline GFCF - RISK & 0,60474 & 0,03925 & 0,30859 & 0,72194 \\
\hline GFCF - UN & 0,20452 & $-0,36332$ & $-0,04232$ & 0,09405 \\
\hline LAB - RISK & $-0,91815$ & $-0,35079$ & $-0,92616$ & $-0,9214$ \\
\hline LAB - UN & $-0,62497$ & $-0,01714$ & $-0,72858$ & $-0,41691$ \\
\hline RISK - UN & 0,66423 & 0,70918 & 0,86742 & 0,52215 \\
\hline
\end{tabular}

We have measured the correlation of selected indicators using the SAS programme. The results are shown in the table above. Firstly, we looked for the relation between foreign direct investments (FDI) and the level of employment in 15 to 64 years of age. In all countries, except Slovakia, there is a positive relationship which means that inflow of foreign investments positively affects the employment rate. The second comparison is related to the first and, as in the 
previous case, there is a positive correlation in all countries except the Slovak Republic. We can see a strong positive relation between FDI and GDP in the Czech Republic and Poland. In Hungary, there is only a small correlation. The third correlation is connected to the first comparison. We tried to find the relation between FDI and gross fixed capital formation (GFCF). This relation confirmed our assumptions that FDI in Slovakia was focused more on the creation or obtaining capital than creating job opportunities. In all countries except Slovakia, there was a negative correlation which means that FDI in these countries are more focused on creating more job opportunities and thus helping the national economy. These assumptions were later confirmed by finding a relation between FDI and labour productivity in V4 countries. In all countries, except for Slovakia, there is a strong positive correlation between FDI and labour productivity which means that FDI are helping in the creation of job opportunities with higher labour productivity which in the end helps the national GDP. Last observation was focused on finding the relation between FDI and the share of people at risk of poverty. As we mentioned before the FDI in case of Slovakia were more focused on creating or obtaining capital than job opportunities. This was also confirmed by our measurements. In Slovakia, there is a strong negative correlation between FDI and share of people at risk of poverty while in other V4 countries there is a strong negative correlation between these two indicators.

Next, we were looking into relation between employment rate in the age group from 15 to 64 years (we will use EM15 for further reference in the text) and other indicators. Firstly, we looked into the relation of EM15 and GDP rate. In all countries, with the exception of Hungary, we found a strong positive correlation. In Hungary, there was only a moderate correlation with the value of 0.38 . The strongest was found in Slovakia. The correlation between EM15 and gross fixed capital formation proved to be negative in all V4 countries which confirmed that investments into capital lead to a decrease in employment. The sound employment rate plays an important role in the economy both in the economic and social point of view. In all V4 countries, we can see rising labour productivity as a result of the rising employment rate. From the social point of view the higher the employment rate the lower the share of the population at risk of poverty. Also, with the rise of $\mathrm{GFCF}$, there is the rise of the share of people at risk of poverty due to an increase in unemployment. We also found a negative correlation between GFCF and labour productivity. This confirms that the rise in the capital may be helpful from the economic point of view on one hand but on the other hand it negatively affects the social side of the economy measured by employment rate and people at risk of poverty. To confirm the connection among the social indicators we decided to measure the correlation of labour productivity and social indicators like unemployment and share of people at risk of poverty. In both cases, we found a negative relationship which means that with higher labour productivity both shares of people at risk of poverty and unemployment will be decreasing. These two indicators have a strong positive relation which shows us that the higher the unemployment rate the higher share of people at risk of poverty. 
The following group was focused on finding the relation between GDP and other indicators. Firstly, we wanted to know if there is a relation between GDP and gross fixed capital formation (GFCF). We found a negative correlation in all V4 countries with different level. For example, in Slovakia, there is a strong negative correlation which suggests that with the decrease of GDP a decrease in GFCF will follow. In the Czech Republic, this relation was moderate and in Hungary and Poland, there was observed weak relation. Since we already saw a positive relationship between the employment rate and GDP and also between the employment rate and labour productivity, there is also a strong relation and medium in Hungary, between GDP and labour productivity which confirms us that with the increase in labour productivity the GDP will also increase. Since GDP is an economic indicator which also affects the social side of the economy we decided to look into the relation between GDP and two social indicators, namely share of people at risk of poverty and unemployment rate. In both cases, there was observed a negative relationship which means that an increase in GDP means a decrease in both social indicators.

\section{Conclusions}

This paper aimed to measure the development of selected economic and social indicators in V4 countries to see their relation to determine the social conditions in each of the countries after the EU accession. To compare the living standards we decided to focus on GDP per capita and saw its rising trend in all V4 countries, the highest in the Czech Republic. On the other hand, Poland has reached the lowest average value of GDP per capita. The condition after entering the EU was developing fairly well in all new member countries. Unfortunately, due to external global negative impact in the form of financial outburst in the $2008-2010$ period led to baleful economic and social development. This condition is best described by the number of unemployed people in our studied countries. After 2008, it was constantly rising until 2010 and was stabilized until 2013. Later on, the number of unemployed people started to decrease. The highest number of unemployed people was measured in Poland and the lowest in the Czech Republic. During this period, the labour productivity was slightly increasing except for the Slovak Republic where almost a twofold increase was recorded. From 2005 to 2017 the direct investments were constantly increasing in all V4 countries except for the Slovak Republic. The highest increase can be seen in Hungary. The difference between Slovakia and Hungary in 2017 is almost threefold. One of the most important indicators to measure the social condition in countries is the number of people at risk of poverty. In V4 countries there was a decreasing trend during the whole period. To find the relations between the chosen economic and social indicators we calculated Pearson's correlation coefficient. Through these calculations, we confirmed correlations among various economic and social indicators. The strongest ones were between the employment rate and labour productivity and share of people at risk of poverty. In the course of research, we encountered several minor limitations. The most serious was the availability of 
comparable data throughout time. This difference was not only between individual countries but also between data available in one statistical database. For future reference, there is an available capacity to focus on more EU member countries and start collecting and analyzing the data for individual EU members and thus determine their economic and social development after entering the EU.

\section{Acknowledgement}

This work was supported by the Grant Agency FESRD projects no. 11-GASPU2018 - Selected aspects of economic policy and its impacts on the business environment in the Slovak Republic.

\section{References}

[1] Andrejovský, P., Gajdoš, J., Hajduová, Z., Andrejkovič, M., (2012) Ecologisation of social development and quality. $12^{\text {th }}$ international multidisciplinary scientific geoconference SGEM 2012, Albena, Bulgaria, 307-312

[2] Androniceanu, A., Tvaronavičienè, M. (2019) Developing a holistic system for social assistance services based on effective and sustainable partnerships. Administratie si Management Public, 33, 103-118, Doi: 10.24818/amp/2019.33-06

[3] Androniceanu, A., Gherghina, R. \& Ciobanasu, M. (2019) The interdependence between fiscal public policies and tax evasion. Administratie si Management Public, 32, 32-41, DOI: 10.24818/amp/2019.32-03

[4] Bajer, I. (2009) Global crisis? Crisis visions of Slovakia. In: Hospodárske noviny. Available at: <https://finweb.hnonline.sk/komentare-aanalyzy/349236-globalna-kriza-kriza-vizie-slovenska>

[5] Baláž V., Karasová K., Williams A. M. (2017) Chapter 5: The V4 Countries and the EU: A Comparative Perspective. In: Fish M., Gill G., Petrovic M. (eds) A Quarter Century of Post-Communism Assessed. Palgrave Macmillan, Cham. ISBN: 978-3-319-43436-0

[6] Barcaccia, B., Esposito, G., Matarese, M., Bertolaso, M., Elvira, M., De Marinis, M. G. (2013) Defining Quality of Life: A Wild-Goose Chase? In: Europe's journal of psychology. Vol. 9, No. 1, 2013, Cit. 24.5.2018, Available at: https://ejop.psychopen.eu/article/view/484/html

[7] Békesi, L. (2011) A Magyar gazdaság helyzete, kilátásai, 2002 - 2010 (Position and perspectives of Hungarian Economy, 2002 - 2010). Stratégiai Tanulmányok a Magyar Tudományos Akadémián. Ezredforduló 1, pp. 1018

[8] Beslerová, S., Dzuričková, J. (2014) Quality of life measurements in EU countries. In: Procedia Economics and Finance. Vol. 12, 2014, pp. 37-47 
[9] Bielik, P. Rajčániová, M. (2008) Shift-share analysis of employment growth - the case of the V4 countries. In: Agric. Econ. - Czech, 54 (2008): issue 8, pp. 347-351

[10] Bloomberg (2009) "Poland's Economic Outlook May Be Raised by IMF, PAP Reports"

[11] Chehabeddine, M.; Tvaronavičienè, M. (2020) Securing regional development, Insights into Regional Development 2(1): 430-442, https://doi.org/10.9770/IRD.2020.2.1(3)

[12] Chocholatá, M., \& Furková, A. (2018) The analysis of employment rates in the context of spatial connectivity of the EU regions. Equilibrium. Quarterly Journal of Economics and Economic Policy, 13(2), 181-213, https://doi.org/10.24136/eq.2018.010

[13] Civelek, M., Ključnikov, A., Krajčík, V., Žufan, J. (2019) The Importance of Discount Rate and Trustfulness of A Local Currency for the Development of Local Tourism. Journal of Tourism and Services, 10(19): 77-92, https://doi.org/10.29036/jots.v10i19.117

[14] Cseh Papp, I., Varga, E., Schwarczová L., Hajós, L. (2018) Public work in an international and Hungarian context. Central European Journal of Labour Law and Personnel Management, 1 (1), 6-16, http://doi.org/10.33382/cejllpm.2018.01.01, ISSN 2644-4542

[15] Czaja, I., Wach, K. (2009) Zmiany obrotów handlu zagranicznego Polski przed akcesją i po akcesji do Unii Europejskiej. Zeszyty Naukowe No. 799, Kraków: Uniwersytet Ekonomiczny w Krakowie. Cit. 20.7.2018. Available at: < https://mpra.ub.uni-muenchen.de/31675/ >

[16] Czech Statistical Office. Available at:

<https://www.czso.cz/csu/czso/home >

[17] Čepel, M. (2019) Social and Cultural Factors and Their Impact On The Quality Of Business Environment In the SME Segment. International Journal of Entrepreneurial Knowledge, 7(1), 65-73, doi: 10.2478/ijek-20190005

[18] Dabrowski, M. (2016) Currency crises in post-Soviet economies - a never ending story?. In: Russian Journal of Economics 2 (2016) 302-326, Available at: <https://rujec.org/article/27973/>

[19] Drozdowicz-Bieć (2013) "Reasons why Poland avoided the 2007-2009 Recession", Collegium of Economic Analysis Discussion Papers, WSE. Cit. 20.6.2018, Available at: <http://kolegia.sgh.waw.pl/pl/KAE/struktura/ IRG/publikacje/Documents/pim86_2.pdf>

[20] Dul'ová Spišáková, E., Mura, L., Gontkovičová, B., Hajduová, Z. (2017) R\&D in the context of Europe 2020 in selected countries. Economic 
Computation and Economic Cybernetics Studies and Research, Vol. 51, No. 4, pp. 243-261, ISSN 0424-267 X

[21] EC. DG for Economic and Financial Affairs. European Economic Forecast Autumn 2009, Cit. 21.6.2018, Available at: <http://ec.europa.eu/ economy_finance/publications/pages/publication16055_en.pdf $\rangle$

[22] EEIP (2010) Project putputs „Impact of economic crisis on civil society“. Cit 21.7.2018, Available at: <http://osf.cz/cs/publikace/vystupy-projektudopady-ekonomicke-krize-na-obcanskou-spolecnost/>

[23] EEIP (2013) Analysis of the impact of the economic crisis on the implementation of structural funds and the cohesion fund in the Czech Republic, Cit. 21.7.2018, Available at: < http://www.eeip.cz/en/files/ 2014/05/140515_Analyza_krize_SF_AJ.pdf>

[24] Egedy, T. (2012) The effects of global economic crisis in Hungary. In: Hungarian Geographical Bulletin 61 (2) 2012, pp. 155-173, ISSN 20645031

[25] Eurostat (2018) Living conditions in Europe 2018 edition, ISBN 978-9279-86498-8, Available

at: $<$ http://ec.europa.eu/eurostat/documents/3217494/

9079352/KS-DZ-18-001-EN-N.pdf/884f6fec-2450-430a-b68d$\mathrm{f} 12 \mathrm{c} 3012 \mathrm{f} 4 \mathrm{~d} 0>$

[26] Eurostat. Available at: < http://ec.europa.eu/eurostat >

[27] FAO (1995) The state of food and agriculture. Rome. 1995. ISBN: 92-5103700-0

[28] Floyd, D. (2016) The European Banking Crisis Explained. In: Investopedia. Cit. on $22^{\text {nd }}$ May, 2018, Available at: <https://www.investopedia.com/ articles/insights/110316/european-banking-crisis-explained-db.asp>

[29] Gnangnon, S. K. Effect of multilateral trade liberalization on foreign direct investment outflows amid structural economic vulnerability in developing countries. In: Research in International Business and Finance 45 (2018) 1529, ISSN: 0275-5319

[30] Hagemejer, J., Tyrowicz, J. (2017) Upstreamness of employment and global financial crisis in Poland: the role of position in the global value chains. In: GRAPE Working Paper no. 15, ISSN: 2544-2473, Available at: < http://grape.org.pl/WP/15_HagemejerTyrowicz_website.pdf >

[31] Healey, N. M. (1994) The transition economic of central and eastern Europe: A political, economic, social and technological analysis. In: The Columbia Journal of World Business, Vol. 29, Issue 1, 1994, pp. 62-70, ISSN: 0022-5428

[32] Hitka, M., Lorincova, S., Bartakova, GP., Lizbetinova, L., Starchon, P., Li, C., Zaborova, E., Markova, T., Schmidtova, J., Mura, L. (2018) Strategic 
Tool of Human Resource Management for Operation of SMEs in the Wood-processing Industry. Bioresources, Vol. 13, No. 2, pp. 2759-2774, ISSN 1930-2126

[33] Hudcovský, M., Lábaj, M., Morvay, K. (2017) Employment Growth and Labour Elasticity in V4 Countries: Structural Decomposition Analysis. In: Prague Economic Papers Vol. 26, No. 4, Available at: <https://doi.org/10.18267/j.pep.623>

[34] Hungarian Central Statistical Office. Available at:

$<$ http://www.ksh.hu/?lang=en >

[35] Jašková, D. (2019) Assessment of social development in Slovakia in the context of human resources. Central European Journal of Labour Law and Personnel Management, 2 (2), 21-32, doi: 10.33382/cejllpm.2019.03.02

[36] Kisel'áková, D., Širá, E., Šofranková, B. (2018) The performance of V4 Countries according to ease of Doing Business Index. Acta Oeconomica Universitatis Selye 7 (2), 71-79

[37] Kräussl, R., Lehnert, T. and Stefanova, D. (2016) The European sovereign debt crisis: What have we learned? In: Journal of Empirical Finance. Vol. 38, part A, 2016, pp. 363-373, ISSN: 0927-5398

[38] Lennartz, C., Arundel, R., Ronald, R. (2015) Younger adults andhomeownership in Europe through the global financial crisis. In: "Population, Space and Place", 2016, Vol. 22, Issue 8, pp. 823-835, ISSN: $1544-8444$

[39] Macours, K., Swinnen, J. F. M. (2008) Rural-Urban Poverty Differences in Transition Countries. In: World Development, Vol. 36, Issue 11, ISSN: 0305-750X [on-line] Available at: <https://www.sciencedirect.com/science/ article/pii/S0305750X08001113>

[40] Miłek, D. (2018) Spatial differentiation in the social and economic development level in Poland. Equilibrium. Quarterly Journal of Economics and Economic Policy, 13(3), 487-507, https://doi.org/10.24136/eq.2018.024

[41] Mitrega-Niestroj, K. (2011) Foreign trade of Poland during the global financial crisis. In: Financial management of firms and financial institutions. Ostrava 2011, ISBN: 978-80-248-2494-9

[42] Mundell, R. A. (1961) "A Theory of Optimum Currency Areas". American Economic Review. 51 (4): 657-665, JSTOR 1812792

[43] Mura, L., Daňová, M., Vavrek, R., Dúbravská, M. (2017) Economic freedom - classification of its level and impact on the economic security. AD ALTA-Journal of Interdisciplinary Research, Vol. 7, No. 2, pp. 154157, ISSN 1804-7890

[44] Mura, L., Vlacseková, D. (2018) Motivation of public employees: case study of Slovak teaching and professional staff. Administratie si 
Management Public (31) pp. 67-80, ISSN 1583-9583, DOI: 10.24818/amp/2018.31-05

[45] Nagy, B. Z. (2016) Regional inequalities in the European Union. Acta Oeconomica Universitatis Selye 5 (1), 109-118

[46] Nickell, S. (1997) Unemployment and labor market rigidities: Europe versus North America, in "The Journal of Economic Perspectives", American Economic Association, Vol. 11, No. 3, pp. 55-74

[47] Nowak, P. (2018) Regional variety in quality of life in Poland. Oeconomia Copernicana, 9(3), 381-401, https://doi.org/10.24136/oc.2018.019

[48] Okanazu, O. O., Madu, M. A., Igboke, S. A. (2019) A recipe for efficient and corrupt free public sector. Central European Journal of Labour Law and Personnel Management, 2 (1), 29-46, doi: 10.33382/cejllpm.2019.02.03

[49] Olczyk, M., \& Kordalska, A. (2018) Determinants of trade balance in Polish and Czech manufacturing sectors. Equilibrium. Quarterly Journal of Economic and Economic Policy, 13 (3), 445-466, doi: 10.24136/eq.2018.022

[50] Pavliková, L', Siničáková, M., (2012) Labor Market Indicators and Their Causalities: the Case of the New European Union Member States, In: "Procedia Economics and Finance". Vol. 3 (2012) pp. 1229-1237, ISSN 2212-5671

[51] PWC. Report on transformation - Central and Eastern Europe Facing the Debt Crisis. Hard Landing 2. Poland 2010, Cit. 15.7.2018, Available at: < https://www.pwc.pl/en/publikacje/hard-landing-2.pdf>

[52] Ram, V. (2009) Crisis Hits Czech Republic. In: Forbes. Cit. on. 25.7.2018, Available at: <https://www.forbes.com/2009/03/25/czech-republiccollapse-markets-equity-crisis.html\#1e3484174324>

[53] Reichardt, A. (2011) Poland and the Global Economic Crisis: Observations and Reflections in the Public Sector, pp. 38-48, In: Journal of Finance \& Management in Public Service, Vol. 10, No. 1, 2011, ISSN: 1475-1283

[54] Rrutkowski J. (2006) Labour Market Developments during Economic Transition. Policy research Working Paper no. 3894, World Bank. Cit. on 25.5.2018. Available at: <https://openknowledge.worldbank.org/handle/ 10986/8710>

[55] Scanlon, T. (1993) Value, desire, and quality of life. In M. Nussbaum \& A. Sem (Eds.), The quality of life (pp. 185-207) Oxford: Oxford University Press

[56] Statistical Office of the Slovak Republic. Available at: 〈www.statistics.sk>

[57] Statistics Poland. Available at: < http://stat.gov.pl/en/ > 
[58] Stiglitz, J. E., Sen, E. A. \& Fitoussi J-P. (2009) Report by the Commission on the Measurement of Economic Performance and Social progress. Cit. on 24.5.2018, Available at: <http://ec.europa.eu/eurostat/documents/ 118025/118123/Fitoussi+Commission+report >

[59] Tomkiewicz, J. (2018) The labour market and income distribution in postsocialist economies - Non-obvious regularities. In: Communist and PostCommunist Studies, Volume 51, Issue 4, December 2018, pp. 315-324, Available at: <https://www.sciencedirect.com/science/article/pii/ S0967067X18300618?via\%3Dihub>

[60] Tvrdoň, M. (2010) Consequences of the global economic crisis on the Czech economy. Scientific papers of the University of Pardubice. Series D, Faculty of Economics and Administration. 17 (2/2010) ISSN: $1211-555 \mathrm{X}$

[61] Volná, J., Papula, J. (2013) Analysis of the Behavior of Slovak Enterprises in the Context of Low Innovation Performance. In: Procedia - Social and behavioral sciences, 2013, Vol. 99, pp. 600-608, ISSN: 1877-0428 